\title{
（63）不整形地盤亡木造家屋の地震被害亡の関係
}

$\begin{array}{lll}\text { 鹿島建設 (株) 技術研究所 } & \text { 正会員 } & \text { 大保直人 } \\ \text { 東電設計 (株) } & \text { 柳下文雄 } \\ \text { 東京電力 (株) 技術研究所 } & \text { 正会員 } & \text { 柴田昌之 } \\ \text { (財) 電力中央研究所 } & \text { 正会員 } & \text { 岩楯做広 } \\ \text { 東京理科大学 } & \text { 正会員 } & \text { 東平光生 } \\ \text { (株) 奥村組筑波研究所 } & \text { 正会員 } & \text { 吉川正昭 }\end{array}$

1. はじめに 過去の被害地震での地盤と地震被害との関係については、すでに数多くの研究機関・研究 者によってそれぞれの調查結果が報告されている。ここでは、不整形地盤と地震被害との関係を解明する ために、1923年関東大地震、1978年宮城県沖地震および1987年千葉県東方沖地震での地震時の地盤震動に よって被害を受けた木造家屋の被害分布と不整形地盤（例えば、周辺地盤構造や地形形状）に注目して再 調查した結果 ${ }^{1)}$ (2)をまとめたすのである。

2. 関東大地震での不整形地盤と地震被害 この地震は、1923年（大正12年）9月1日午前11時58分に、震 央を東経 $139.3^{\circ}$ 、北緯 $35.2^{\circ}$ とし、マグニチュード7.9、であった。その震源は、相模トラフから沈み込 むフィリピン海プレート上面が日本をのせる アジアプレートの下面に接するところに生じ る断層運動により発生したものと考えられて いる。被害地域は、東京府・神奈川県を中心 に、関東一円に及び、さらに、長野・山梨・ 静岡の各県でも被害を出している。このうち、 震源域から近いため被害が著しく大きかった 地域は、神奈川県南部から、房総半島南端部 にかけてであった。一方、震源域から離れて いるが、地盤条件が悪かったために被害が大 きかった地域は、東京の下町低地から埼玉県 の中川低地にかけてであった。

図一には、震源域から比較的離れており、 地盤条件の差が被害に顕著に効き、かつ山地、 台地、平野等の地形がはっきりしている埼玉 県を中心に『震災予防調查会報告』 ${ }^{3)}$ に基づ いて作成した関東地震による木造家屋の被害 率分布を示す4’。なお、図の郡市区町村界は、 主に陸地測量部発行の 20 万分の 1 帝国図（明 治 40 年から大正 5 年までに製版され、図幅に よっては昭和10年までに修正改版されたすの) の境界によった。同図から、関東地震の震動 による家屋の倒壊は、「大宮台地」などに隣 接する台地の縁辺部で顕著であることがわか る。中川低地の春日部市や草加市、荒川低地 の浦和市や志木市や川越市などがその地域に

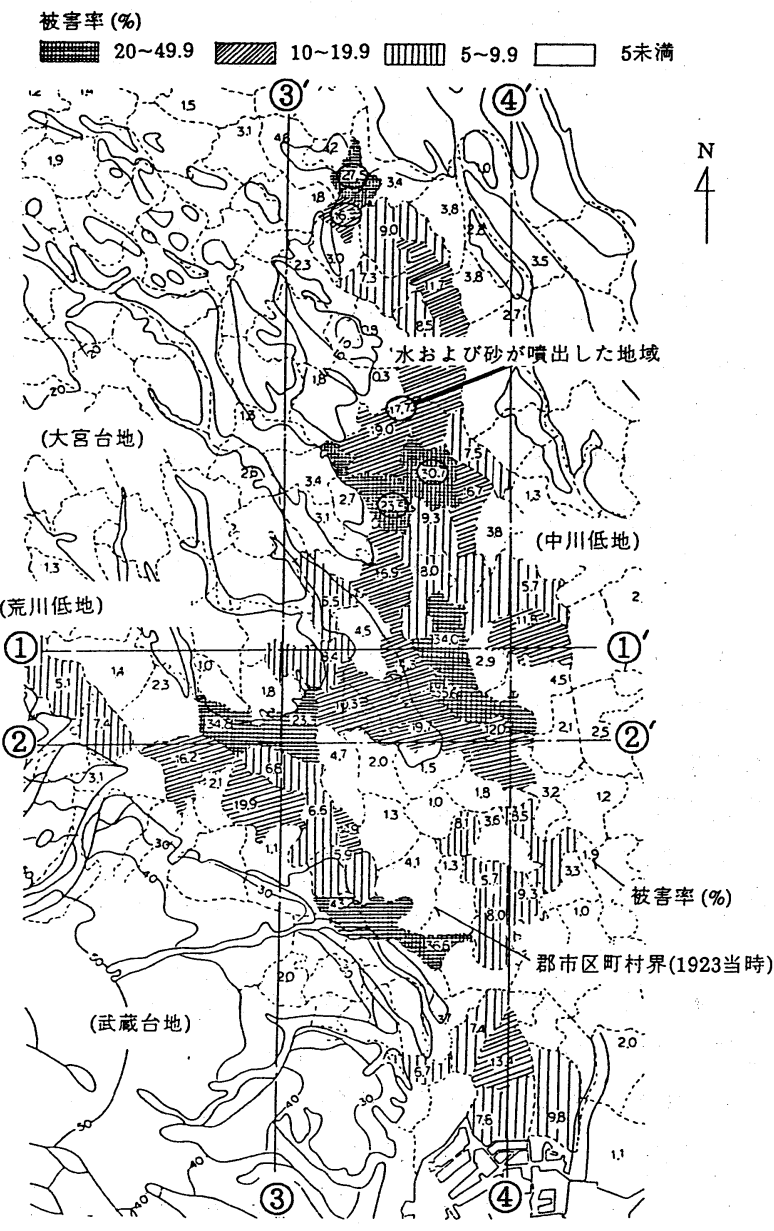

図-1 関東地震による木造家屋の被害率（全壊率）分布 

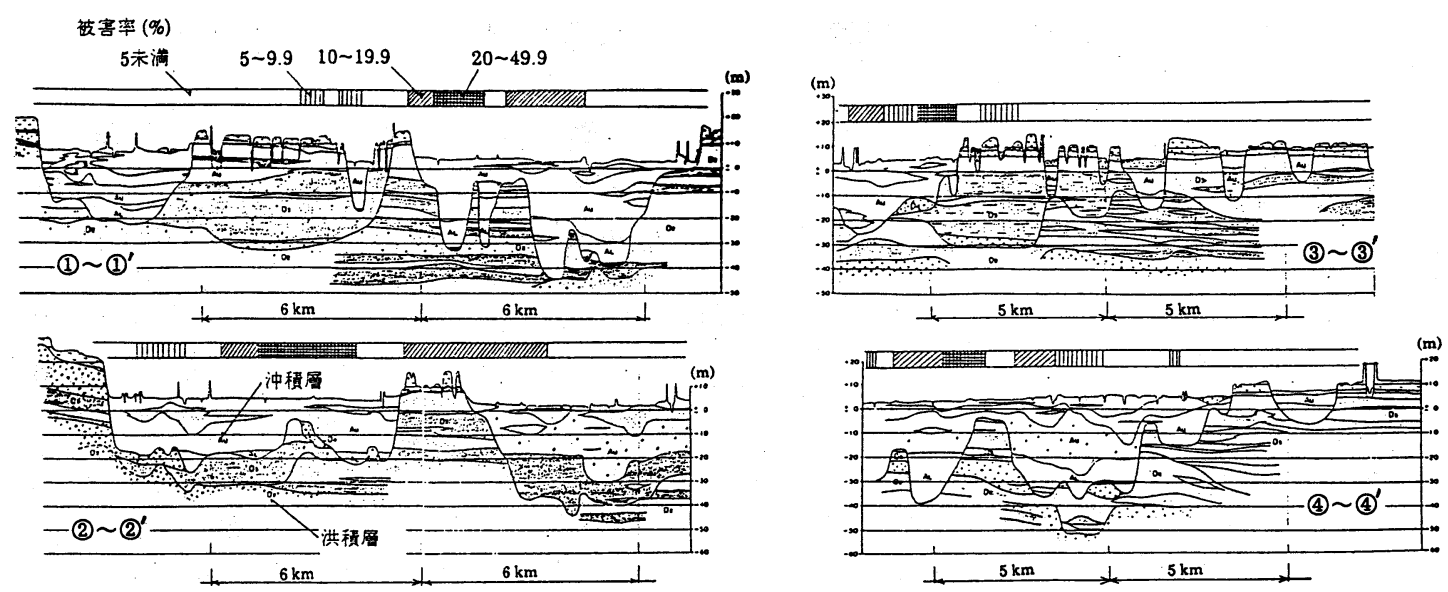

図-2 木造家屋の被害率分布と地質構造の関係

（図-1の(1)〜 (1)', (2)〜 (2)', (3)〜 (3)', (4)〜 (4)' 断面)

あたる。なお、『埼玉県地震調查報文』 ${ }^{5}$ に

”水および砂が噴出”の記述のある地域の被 害率を○で囲んであるが、これによると中川 低地で被害率の高かった地域のうち、北側に 位置する武里や川通は液状化が原因とした被 害と考えられる。

図-1に示した被害率が20\%以上であった 3

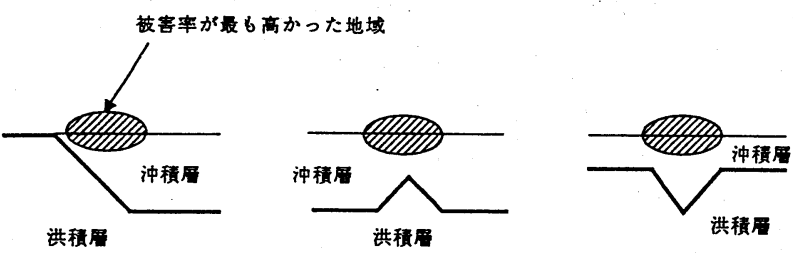
地域のうち、液状化が生じた可能性があった中川低地北側の区域を除く東西・南北 2 箇所を通る代表的な (1)〜 (1)' 、 (2)〜 (2)' 、(3) (3)' 、(4) (4)' の地質断面 ${ }^{6)}$ と被害率の関係を図-2に示す。これらの図より、 関東大地震による木造家屋の被害が集中した地域は図-3に示すような地質構造（またはそれらの組合せ） を有する地点であることがわかる。

3. 宮城県神地震での不整形地船と地震被害この地震は、1978年（昭和53年）6月12日17時14分に、震 央位置を東経 $142.2^{\circ}$ 、北緯 $38.2^{\circ}$ とし、マグニチュード7.4、であった ${ }^{7}$ 。この地震での地震動の観湘結果 によれば、最大加速度は軟弱地盤上および丘陵地においては約250〜300 gal、硬質地盤上では約150〜200g alであり強震（震度V）ないし烈震（震度VI）に相当している。

図-4は、長町駅付近の木造家屋の被害分布を示したすのである。図中の黒の印は造成地盤の被害（盛土 の崩壊、地盤の移動）が主要因のものを示し、白○印は振動現象が主要因のものを示したものである5 。 丘陵地にある緑っ丘団地は、造成地盤の被害が主要因と考えられる木造家屋被害が集中しているのに対し、 振動現象による木造建物の被害は、長町駅周辺の貝塚、荒井などの沖積平野部に集中している。この地震 による仙台市における木造家屋の被害をまとめると、

(1)盛土の崩壊、地盤の移動に起因する、地盤被害が主要因と考えられる木造家屋被害が丘陵地の宅地造成 地に分布していること、

(2)振動現象が主要因と考えられる木造建物被害は沖積層平野部に分布していること、

(3)特に振動現象による被害は、基盤構造が急変する丘陵地と沖積平野部との境界部分に集中しており、地 盤の不整形性が構造物被害に影響している可能性があることが指摘されている7”。

仙台地域の基盤構造は、長町一利府構造線を境に急変しており、諸機関において行われたボーリング調 查により、図-4に示したを30秒間隔の緯度・経度の地質断面が詳細に調べられている。

図-4で示された30秒間隔のメッシュに沿った東西および南北方向の地質断面と木造家屋被害の関係を調 

E 15 E 01
E 03
E 05
E 07
E 09

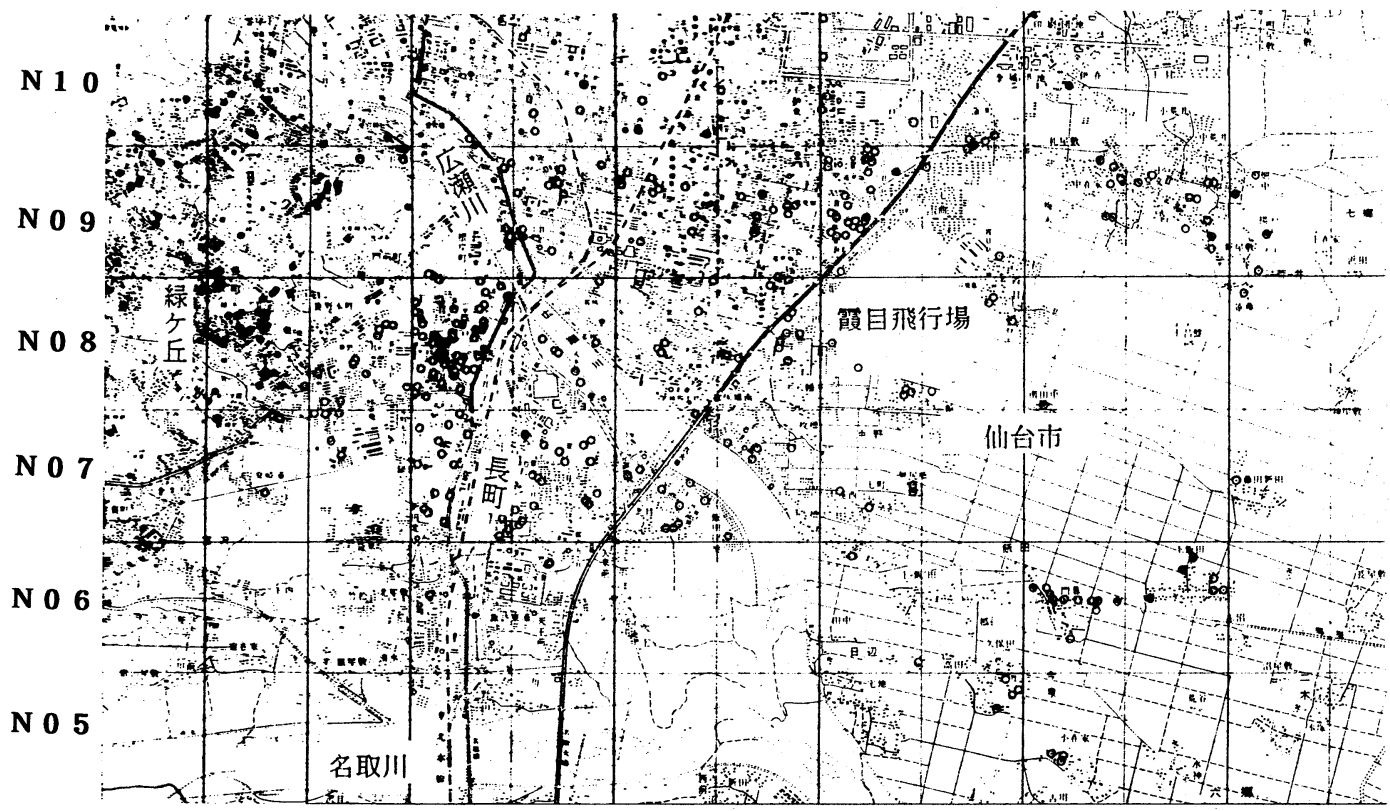

図-4 仙台市における被害を受けた木造家屋の分布（文献7)より）

らべるために、地質断面上の 30 秒每の緯度

・経度の交差点から15秒の範囲で囲まれた 四辺形の中に存在する木造家屋被害件数を us rownan SHotoma その点の代表值として求めた。図-5には、 長町付近の東西方向の地質断面と木造家屋 の被害件数の分布を示した。これらの図よ り、地盤被害が主要因と考えられる木造建 物被害が丘陵地の宅地造成地に分布してい ること、振動現象が主要因と考えられる木 造建物被害は、沖積平野部に分布している ことが分かる。特に、振動現象による被害 は、基盤構造が急変する丘陵地と沖積平野 部との境界部分に被害が集中しており、地 盤の不整形が構造物被害に影響しているこ とを示唆している。

\section{4. 千葉県東方沖地震での不整形地盤と地}

震被害 この地震は、1987年12月17日11時 8 分に発生し、震央位置は北緯 35.4 度、東
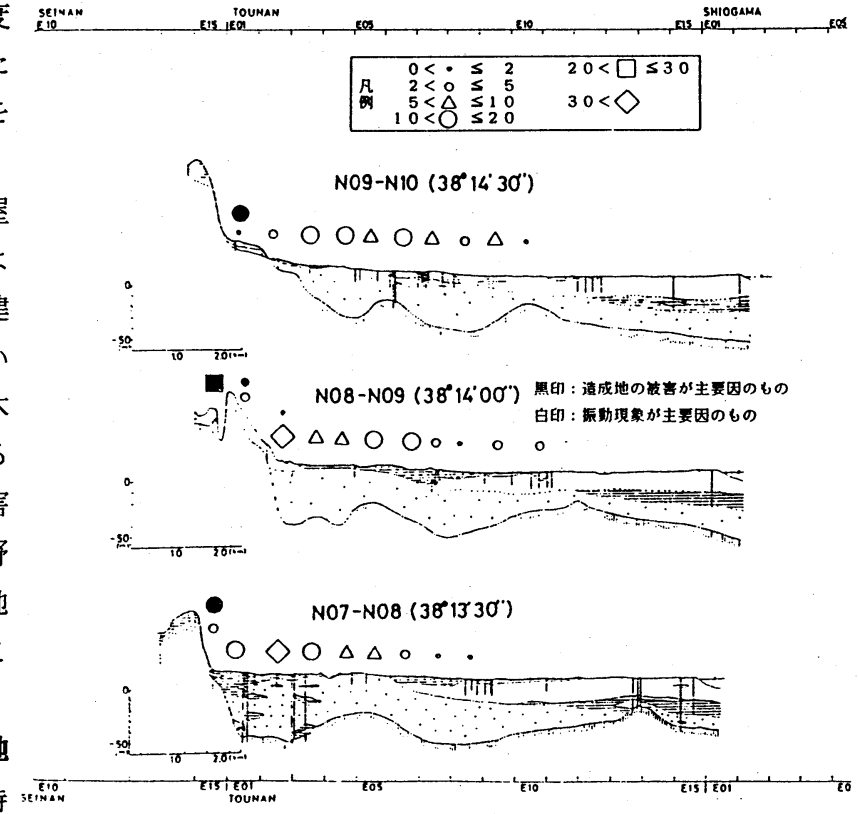
経140.5度であった。また、マグニチュード6.7であった。

この地震の被害は、県中部を中心にほぼ県内全域に及んだ。被害状況として、以下の 5 点が挙げられる。 (1)ブロック塀の倒壊、(2)土砂崩れ、(3)屋根瓦の落下、(4)地盤の液状化、(5)ライフラインの被害

これらの地震被害の中で振動現象に伴う被害として屋根瓦の被害がある。そこで屋根瓦の被害が著しか った千葉、山武、長生支庁管内を中心とする地域を対象として、東西約 $40 \mathrm{~km}$ 、南北約 $55 \mathrm{~km}$ の範囲の被害状 
況を航空写真を用いて調查されている。昭和62年に 実施された「千葉県東方沖地震被害実態調査」 ${ }^{8}$ の 航空写真 $(1 / 4000)$ を用いた調查結果から屋根瓦が被》 害を受けたと判定できる建物を抽出し、屋根瓦の被 害分布のコンターを表層地質図に重ねて書いたもの を図-6に示した。この図より、東半部の地域で屋根 瓦被害が高かったことがわかる。特に、下総台地縁 辺部ないしはその直下の低地に位置する松尾町、成 東町、東金市、大網白里町で屋根瓦被害率が高い。 さらに、九十九里平野南部の茂原市、長生村、一宮 町、白子町であ同様である。特に、東金市、成東町 は、台地の縁辺部に位置しており、地盤不整形に関 連が深いと考えられる。

図-7には図-6に示した東金市を横断する A - A 測 線に沿った地質断面と屋根瓦の被害率の関係を示し た。これからす東金市付近、すなわち 丘陵縁辺部およびその直下の低地で被 害が大きいことがわかる。これは地表 面および表層地盤の不整形に関連が深 いことがうかがえる。また、この結果 は図一ー7示したように東金付近での洪 積層の泥質砂岩の不整形にす関係があ るすのと考えられる。

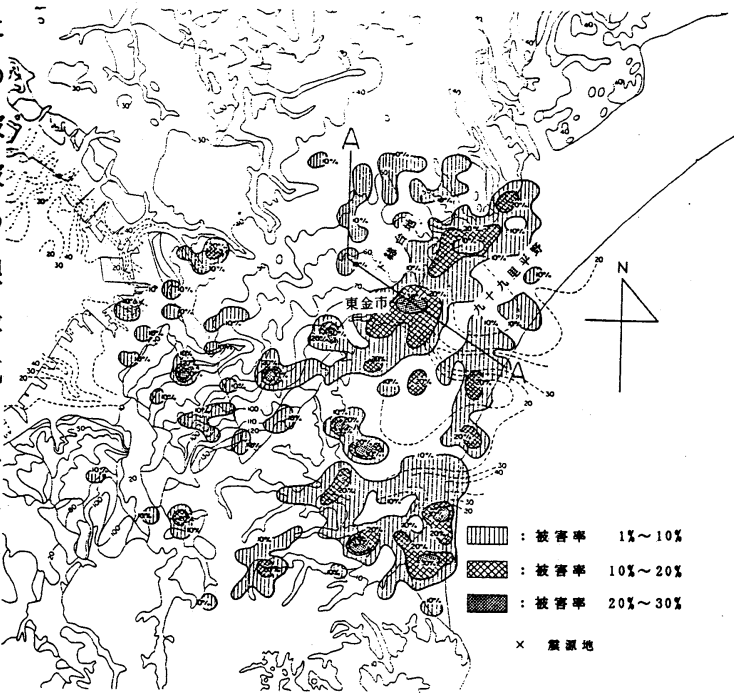

図-6 屋根瓦の被害分布

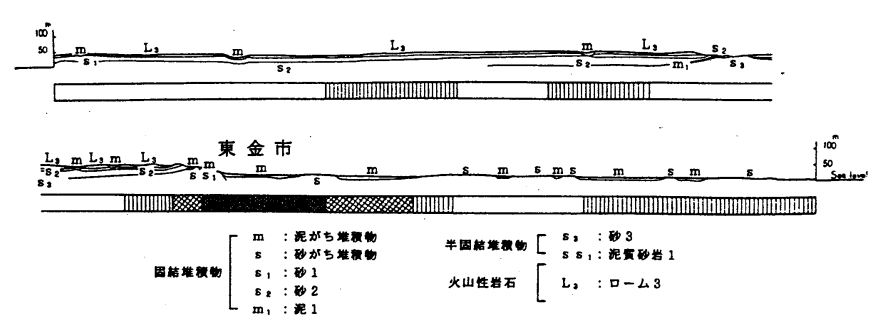

5 . まとめ 木造家屋の地震被害は、宅地造成地の被害つまり地盤被害に起因するすのと地震動によるす の分類される。ここでは、地震動を原因とした木造家屋の地震被害と不整形地盤の関係を明確にするため に1923年関東大地震、1978年宮城県沖地震および1987年千葉県東方沖地震の被害報告の再整理、さらに被 害発生付近の地質条件図や断面図を入手しその関係を調べた。その結果地震動に起因する木造家屋の被害 は、3 地震での地質断面と木造家屋被害率や件数から図-3に示したような地質断面図で表せる不整形地盤 地域に被害が集中する傾向にあることが確認できた。千葉県東方沖地震の地震被害については、深さに関 する地盤条件の変化を示すデータを収集し、検討を進める必要がある。今後、地震被害と不整形地盤の関 係を定量的に明らかにするために、地震応答解析を実施する予定である。

なお、本研究は、日米共同研究「地震時の地盤挙動の解析とライフライン施設の耐震性に関する研究」 （委員長 : 久保慶三郎東京大学名誉教授、事務局：（財）地震予知総合研究振興会）の一環として実施し たすのである。また、東京工業大学大町達夫教授扔び分科会メンバーには、貴重な御助言を頂いた。さ らに、図-2に示した地質断面図は、埼玉県の『大規模地震被害想定調査』において作成されたすのであり、 同県環境部消防防災課より提供して頂いた。ここに記して深甚なる感謝を表する。

【参考文献】1）(財）地震予知総合研究振興会: 平成 2 年度調查・研究報告書、平成 3 年 6 月、2）（財） 地震予知総合研究振興会: 平成 3 年度調查 - 研究報告書、平成 4 年 6 月、3) 今村 : 関東大地震調查報告 「震災予防調查会報告、第百号甲」、1925、4)貝塚、松田 : 首都圏の活断層・地形区分と関東地震の被害 分布図、内外地図、1982、5)地質調查所 : 関東地震調查報告書第一、第二、地質調查所特別報告第 1 号、 $1925 、 6)$ 埼玉県 : 大規模地震被害想定調查一中間報告書一、平成 2 年 3 月、7) 日本建築学会 : 1978 年宮城 県沖地震災害調查報告、8) 千葉県 : 昭和62年 (1987年) 千葉県東方沖地震 - 災害記録 - 